\title{
ANALISIS PERLAKUAN AKUNTANSI ASET TETAP PADA PT. MASSINDO SINAR PRATAMA MANADO
}

\author{
Nurjana Noe \\ Jantje Tinangon \\ Inggriani Elim \\ Fakultas Ekonomi Jurusan Akuntansi \\ Universitas Sam Ratulangi Manado \\ email: noe.anna@yahoo.com
}

\begin{abstract}
ABSTRAK
Semakin pesatnya pelaksanaan pembangunan di berbagai sektor industri yang didukung oleh kemajuan teknologi dan globalisasi pasar internasional akan berdampak pada timbulnya persaingan yang ketat diantara perusahaan, khususnya yang bergerak dalam bidang industri. PT. Massindo Sinar Pratama adalah salah satu perusahaan swasta yang ada di Manado, Sulawesi Utara yang bergerak di bidang manufaktur.Untuk dapat menunjang dan memperlancar kegiatan operasional perusahaan makadiperlukan asset tetap. Peranan akuntansi aktiva tetap sangat diperlukan oleh pengambilan keputusan.Adapun tujuan dari penelitian ini adalah untuk menilai sejauh mana perusahaan telah menerapkan teori yang sesuai dengan Pernyataan Standar Akuntansi Keuangan (PSAK) no. 16. Penelitian ini menggunakan metode analisis deskriptif-komparatif. Dalam penelitian ini hanya difokuskan pada asset tetap mesin. Hasil penelitian menunjukan bahwa dalam pengakuan, pengukuran, pengeluaran setelah perolehan asset tetap, penyusutan asset tetap dan penyajian asset tetap, PT. Massindo Sinar Pratama Manado telah menerapakan kebijakan akuntansi yang mengarah pada Pernyataan Standar Akuntansi Keuangan (PSAK) No. 16.
\end{abstract}

Kata kunci: asset tetap, psak no.16

\section{ABSTRACT}

The rapid implementation of development in various industry sectors, supported by advances in technology and the globalization of international markets will have an impact on the onset of intense competition among enterprises , especially those engaged in the industry. PT. Massindo Sinar Pratama is a private company which is in Manado, North Sulawesi engaged in manufacturing. To be able to support and facilitate the operations of the company's fixed assets required. The role of fixed asset accounting is required by the decision. The purpose of this study was to assess the extent to which the company has applied the theory in accordance with Statement of Financial Accounting Standards ( SFAS ) no. 16. This study used a descriptive - comparative method of analysis. In this study only focused on fixed assets engines . The results showed that the recognition, measurement, after the acquisition of fixed assets expenses, depreciation of fixed assets and fixed asset presentation, PT . Massindo Sinar Pratama Manado applying accounting policies that have led to to the Statement of Financial Accounting Standards ( SFAS ) No. 16

Keywords : fixed assets, SFAS no.16 


\section{Latar Belakang}

\section{PENDAHULUAN}

Perusahaan pada umumnya tidak mengakui keharusan dalam menurunkan nilai aset tetap yang dipakai dalam perusahaan, dengan cara mengadakan penyusutan terhadap aset tetap itu sendiri. Pengeluaran aset tetap dalam jumlah yang tidak material dibebankan sebagai biaya, tetapi apabila nilai pengeluarannya material harus dikapitalisasi ke aset tetap atau menambah nilai aset tetap. Namun seringkali di Perusahaan Pengeluaran yang berhubungan dengan aset tetap ini dicatat sebagai biaya pemeliharaan dan dibebankan sebagai biaya operasional pada perhitungan laba rugi pada saat terjadinya pengeluaran tanpa memandang nilai material yang dikeluarkan sehingga laporan yang disajikan oleh perusahaan tidak wajar karena tidak sesuai dengan Pernyataan Standar Akuntansi Keuangan. Pengeluaran mengenai penggunaan aset tetap perusahaan yang ditampung dalam rekening

" Biaya Pemeliharaan" tanpa memandang sifat dan pengaruhnya pada aset tetap yang bersangkutan.

Berdasarkan latar belakang masalah yang dikemukakan di atas, maka perlu untuk memahami lebih jauh mengenai kebijakan akuntansi aset tetap yang diterapkan perusahaan dan membandingkannya dengan teori yang dipelajari. Penulis pun memilih judul "Analisis Perlakuan Akuntansi Aset Tetap Pada PT Massindo Sinar Pratama Manado". Dengan ini penulis dapat menilai sejauh mana perusahaan telah menerapkan kebijakan aset tetap yang sesuai dengan teori, dimana berdasarkan Pernyataan Standar Akuntansi Keuangan (PSAK) No.16.

\section{Perumusan Masalah}

Dari uraian diatas mengenai latar belakang penelitian maka penulis mencoba merumuskan masalah yaitu apakah perlakuan akuntansi terhadap aset tetap pada PT. Massindo Sinar Pratama Manado telah sesuai dengan PSAK No.16?

\section{Tujuan Penelitian}

Tujuan dalam penelitian ini yaitu untuk menganalisis apakah perlakuan akuntansi terhadap aset tetap pada PT. Massindo Sinar Pratama Manado telah sesuai dengan PSAK No.16.

\section{Manfaat Penelitian}

Hasil penelitian ini diharapkan dapat memberi manfaat antara lain:

a) Manfaat Teoritis

Memberi manfaat bagi pengembangan ilmu pengetahuan khususnya di Bidang ilmu akuntansi, dan dapat menjadi referensi bagi peneliti lainnya untuk mengadakan penelitian selanjutnya yang ada kaitannya dengan aset tetap pada PSAK No.16.

b) Manfaat Praktis

1. Bagi Investor, diharapkan dapat menjadi bahan masukan untuk pengambilan keputusan.

2. Bagi pihak Manajemen

Sebagai bahan pertimbangan dan masukan tentang bagaimana perlakuan akuntansi aset tetap yang ada pada PSAK No. 16 sehingga dapat diterapkan pada perusahaan.

3. Bagi Penulis

Dapat menambah wawasan dan pengetahuan, khususnya mengenai pernyataan standar akuntansi keuangan (PSAK) No.16 tentang aset tetap.

\section{Pengertian Akuntansi}

\section{TINJAUAN PUSTAKA}

Menurut A Statement of Basic Accounting Theory (ASOBAT) yang diterbitkan oleh American Accounting Association pada tahun 1966, Akuntansi didefinisikan sebagai: "proses mengidentifikasi, mengukur, dan menyampaikan informasi bagi para penggunanya dalam mempertimbangkan berbagai alternative yang ada dan membuat kesimpulan”(Hery, $2013: 3$ ).

Menurut Charles T. Horngren, dan Harrison (2009 : 4) menyatakan bahwa: "Akuntansi adalah sistem informasi yang mengukur aktivitas bisnis, memproses data menjadi laporan, dan mengkomunikasikan hasilnya kepada para pengambil keputusan".

Secara umum, akuntansi dapat didefinisikan sebagai sistem informasi yang menghasilkan laporan kepada pihak-pihak yang berkepentingan mengenai aktivitas ekonomi dan kondisi perusahaan.

Dari pengertian diatas dapat diketahui bahwa akuntansi adalah suatu sistem informasi yang meliputi proses mengidentifikasikan, mengukur, dan melaporkan informasi ekonomi dan mengkomunikasikan hasilnya dalam bentuk laporan keuangan diinformasikan kepada pengguna laporan keuangan untuk dijadikan sebagai pertimbangan pengambilan keputusan. 


\section{Pengertian Aset Tetap}

Aset tetap adalah kekayaan perusahaan yang memiliki wujud, mempunyai manfaat ekonomis lebih dari satu tahun, dan diperoleh perusahaan untuk melaksanakan kegiatan perusahaan, bukan untuk dijual kembali (Suhayati \& Anggadini, 2009: 247).

Menurut Sumarsan (2011: 56), Aktiva tetap (fixed assets) merupakan aktiva yang dibeli perusahaan dengan nilai yang relative tinggi untuk digunakan dalam operasional perusahaan untuk jangka waktu yang lebih dari satu tahun.

Aktiva tetap adalah aktiva-aktiva dengan sifat yang tidak bisa dikonversikan menjadi uang tunai dalam siklus operasi perusahaan. Termasuk didalamnya adalah bangunan, peralatan dan tanah atau properti berwujud yang diinginkan dalam suatu bisnis, tetapi tidak diharapkan untuk digunakan habis atau dikonfirmasikan menjadi dana tunai dalam perjalanan bisnis biasa (Sumadji, dkk. 2006: 311).

Dari beberapa pengertian di atas dapat diketahui bahwa pengertian aset tetap itu adalah aset yang meliputi kriteria sebagai berikut:

1. Mempunyai bentuk fisik

2. Mempunyai masa manfaat lebih dari satu tahun

3. Dipergunakan untuk membantu aktivitas perusahaan

4. Tidak dimaksudkan untuk dijual

5. Diharapkan dapat memberikan masa manfaat dimasa yang akandatang

\section{Perolehan Aset Tetap}

Dalam memperoleh aset tetap dapat dilakukan dengan cara, yaitu :

1. Pembelian tunai

Harga perolehan aset tetap yang dibeli dengan tunai meliputi semua pengeluaran dan pembayaran yang terjadi untuk mendapatkan aset tetap tersebut sampai pada kondisi siap pakai untuk digunakan.Pembelian aset tetap secara tunai dicatat sebesar uang yang dikeluarkan untuk pembelian tersebut ditambah biaya-biaya lain sehubungan dengan pembelian aset tersebut termasuk biaya pengangkutan, biaya pemasangan aset tetap dan biaya-biaya lain.Adapun jurnal untuk mencatat transakasi ini adalah dengan mendebet rekening aset tetap dan mengkredit rekening kas.

2. Pembelian secara kredit

Pembelian secara kredit mengakibatkan adannya penagguhan pembayaran. Hutang biasanya dibuktikan dengan wesel, surat berharga, hutang hipotik. Hutang ini dibayar dengan beberapa kali angsuran ditambah dengan pembayaran bunganya.Hal ini berarti pembelian secara kredit membutuhkan pembayaran lebih besar dari pada membeli tunai.Adapun jurnal pada saat pembelian kredit aset tetap adalah dengan mendebit aset tetap dan mengkredit hutang dagang.Sedangkan jurnal pembayaran angsuran bunga adalah mendebit rekening hutang dagang dan biaya bunga dan mengkredit rekening kas.

3. Pembelian dengan surat berharga

Aset tetap yang diperoleh dengan mengeluarkan surat-surat berharga berupa saham atau obligasi dicatat sebesar harga pasar atau obligasi pada saat perolehan aset tersebut.Selisih antar harga pasar saham/obligasi tersebut dengan nominalnya dicatat sebagai agio atau disagio saham /obligasi. Jika surat berharga dan aset tetap tidak memiliki nilai pasar, maka perolehan dapat diterapkan oleh pimpinan perusahaan atau dewan komisaris.

4. Diterima dari sumbangan

Perusahaan dapat memperoleh aset tetap dari sumbangan atau bantuan pemerintah atau badan-badan lain. Transaksi ini disebut dengan "nonrespirocal transfer"atau transfer yang tidak memerlukan umpan balik. Aset ini harus dicatat sebesar harga pasar yang wajar atau berdasarkan penilaian yang dilakukan oleh pihak atau perusahaan penilai independen dan dikredit sebagai modal donasi.Adapun jurnal untuk mencatat aset tetap yang diperoleh dari donasi adalah dengan mendebet rekening aset tetap dan mengkredit rekening modal donasi.

5. Aset Tetap Diperoleh dengan Membangun Sendiri

Perusahaan sering melakukan pembangunan sendiri atas aset tetap yang digunakan, untuk itu perusahaan menggunakan jasa kontraktor atau mempekerjakan buruh dan tenaga ahli untuk membuatnya.Terdapat beberapa faktor yang mempengaruhi perusahaan dalam memenuhi kebutuhan aset tetap dengan membangunnya sendiri, antara lain :

a. Menekan biaya 
b. Keinginan untuk mendapatkan mutu yang lebih baik

c. Memanfaatkan fasilitas yang menganggur

d. Aset tetap yang dibutuhkan tidak dijual dipasaran

Biaya-biaya yang dikeluarkan untuk membangun suatu aset tetap perusahaan, yaitu biaya langsung dan tidak langsung. Biaya langsung termasuk bahan baku, upah langsung dan dibebankan langsung ke aset tetap perusahaan. Lain halnya dengan biaya tidak langsung, maka biaya ini ada yang dibayar keluar perusahaan dan ada yang dibayar kedalam perusahaan. Biaya tidak langsung ini dapat dibebankan menjadi biaya (cost) aset tetap apabila dibayar keluar perusahaan sedangkan yang dibayar kedalam perusahaan tidak dapat dibedakan menjadi biaya (cost) aset tetap.

6. Pertukaran atau tukar tambah

Di dalam PSAK 16 tahun 1994 sebelumnya membedakan pelakuan pencatatan atas pertukaran aset tetap yang sejenis/serupa (Par.21) serta pertukaran aset tetap tidak sejenis/serupa (Par.20), sedangkan PSAK 16 (Revisi 2007) tidak membedakannya. Menurut PSAK 16 (Revisi 2011) Par.24 menyatakan bahwa untuk pertukaran aset tetap, biaya perolehan diukur pada nilai wajar kecuali (a) transaksi pertukaran tidak memiliki substansi komersial; atau (b) nilai wajar dari aset yang diterima dan diserahkan tidak dapat diukur secara andal.

Dalam menetapkan besarnya nilai perolehan aktiva tetap berlaku prinsip harga perolehan yang menyatakan bahwa semua pengeluaran yang terjadi sehingga aktiva tersebut siap digunakan, karena aset tetap itu bermacam-macam dengan uraiannya sebagai berikut:

\section{Tanah}

Harga perolehan tanah terdiri dari berbagai elemen seperti; harga beli, komisi pembelian, bea balik nama, biaya penelitian tanah, iuran-iuran (pajak-pajak) selama tanah belum dipakai, biaya merobohkan bangunan lama, biaya perataan tanah, pajak-pajak yang jadi beban pembeli tanah pada waktu pembelian tanah. Biaya-biaya yang dikeluarkan untuk memperbaiki keadaan tanah tetapi mempunyai umur yang terbatas tidak dikapitalisasi dalam rekening tanah tetapi dicatat sendiri dalam rekening jalan-jalan dan jembatan.Biaya-biaya seperti itu misalnya biaya untuk membuat jalan, trotoar, dan saluran air.Jika tanah dimiliki untuk tujuan investasi, maka semua biaya yang timbul dalam hubungannya dengan tanah tersebut selama masa pemilikan dikapitalisasi menambah harga perolehan.

2. Bangunan

Biaya yang dikapitalisasi sebagai harga perolehan gedung adalah; harga beli, biaya perbaikkan sebelum gedung itu dipakai, komisi pembelian, bea balik nama, pajak-pajak yang menjadi tanggungan pembeli pada waktu pembelian. Apabila gedung itu dibuat sendiri maka harga perolehan gedung terdiri dari; biaya-biaya pembuatan gedung, biaya perencanaan, biaya pengurusan izin bangunan, pajak-pajak selama masa pembangunan gedung, bunga selam pembuatan gedung, asuransi selama masa pembangunan. Alat-alat perlengkapan gedung seperti tangga berjalan, lift dan lain-lain dicatat tersendiri dalam rekening alat-alat gedung dan akan didepresiasi selama umur alat-alat tersebut.

3. Mesin dan Alat-alat

Yang merupakan harga perolehan mesin dan alat-alat adalah; harga beli, pajak pajak yang menjadi beban pembeli, biaya angkut, asuransi dalam perjalanan, biaya pemasangan, biaya-biaya yang dikeluarkan selama masa percobaan mesin.Apabila mesin itu dibuat sendiri maka harga perolehannya terdiri dari semua biaya yang dikeluarkan untuk membuat mesin. Mesin yang disewa dari pihak lain, biaya sewanya tidak dikapitalisasi tetapi dibebankan sebagai biaya pada periode terjadinya.

4. Kendaraan

Yang termasuk harga perolehan kendaraan adalah harga faktur, bea balik nama dan biaya angkut. Pajakpajak yang dibayar setiap periode seperti pajak kendaraan bermotor, jasa raharja, dan lain-lain dibebankan sebagai biaya pada periode yang bersangkutan.Harga perolehan kendaraan ini didepresiasi selama masa kegunaannya.

\section{Pengukuran Aset Tetap}

Adapun mengenai pengukuran aset tetap dapat dibagi ke dalam dua bagian, yaitu :

1. Pengukuran Awal Ketika Aset Tetap tersebut diperoleh

Aset tetap yang memenuhi kualifikasi untuk dikategorikan sebagai aset tetap pada awalnya diukur sebesar biaya perolehan.Biaya perolehan aset tetap adalah jumlah biaya yang dikeluarkan oleh entitas dan diperlukan untuk menyiapkan aset tetap tersebut agar dapat digunakan sebagaimana mestinya sebagai aset tetap. Biaya perolehan aset tetap menurut PSAK 16 Revisi Tahun 2011adalah : 
a. Biaya Perolehan, termasuk bea impor dan pajak pembelian yang tidak boleh dikreditkan setelah dikurangi dengan diskon pembelian dan potongan lain.

b. Biaya-biaya yang dapar diatribusikan secara langsung untuk membawa aset ke lokasi dan kondisi yang diinginkan dan maksud manajemen. Contoh biaya yang dapat diatribusikan secara langsung adalah :

1) biaya persiapan tempat

2) biaya penanganan dan penyerahan awal

3) biaya perakitan dan instalasi

4) biaya pengujian aset apakah dapat beroperasi dengan baik, setelah dikurangi hasil penjualan dari produk yang dihasilkan atas pengujian tersebut.

5) komisi profesional seperti arsitek dan insinyur

c. Estimasi biaya pembongkaran dan pemindahan aset tetap dan restorasi lokasi aset.

Pada umumnya nilai perolehan suatu aset tetap sama dengan jumlah biaya (bisa berupa kas maupun non-kas) untuk memperoleh aset tersebut. Selain itu, aset tetap dapat diperoleh dari pertukaran aset non moneter.Prinsip utama padapengukuran aset tetap yang diperoleh dari pertukaran aset tetap ini adalah dengan menggunakan nilai wajarnya, dalam hal ini nilai wajar aset tetap yang dipertukarkan tidak diketahui, nilai buku aset tersebut dapat digunakan.

2. Pengukuran Setelah Pengakuan Awal

Pengeluaran aset tetap selain dilakukan pada awal perolehan juga dilakukan pada periode setelah aset tetap tersebut diperoleh.Di dalam PSAK 16 (Revisi 2011) terdapat perubahan yang signifikan mengenai perlakuan akuntansi aset tetap terutama tentang pengeluaran nilai aset tetap setelah perolehan.PSAK 16 (Revisi 2011) mengakui adanya dua metode dalam perlakuan akuntansi aset tetap tersebut. Kedua metode itu adalah:

a. Metode Biaya Historis ( PSAK Tahun 1994 dan PSAK Revisi 2011). Dengan metode ini setelah aset tetap diakui sebagai aset tetap, aset tetap tersebut dicatat pada harga perolehan dikurangi dengan akumulasi penyusutan dan akumulasi rugi penurunan nilai aset.

b. Metode Revaluasian (PSAK Revisi 2011)

Dengan metode ini setelah aset tetap diakui sebagai aset tetap, suatu aset tetap yang nilai wajarnya dapat diukur secara andal harus dicatat pada jumlah revaluasi, yaitu nilai wajar pada tanggal revaluasi dikurangi akumulasi penyusutan dan akumulasi rugi penurunan nilai yang terjadi setelah tanggal revaluasi.Revaluasi atas aset tetap harus dilakukan dengan keteraturan yang cukup reguler untuk memastikan bahwa jumlah tercatat tidak berbeda secara material dari jumlah yang ditentukan dengan menggunakan nilai wajar pada tanggal neraca.

Dari uraian tersebut dapat diketahui bahwa pengukuran aset tetap terjadi ketika pengakuan awal dan setelah aset tetap telah diakui.Pengukuran aset pada saat pengakuan awal dilakukan dengan mengukur semua biaya perolehan.Dan ketika aset telah diakui perusahaan, mengukur aset menggunakan dua metode yaitu metode biaya dan metode revaluasi.

\section{Penyusutan dan Metode Penyusutan Aset Tetap}

Menurut Standar Akuntansi Keuangan (2009: 17.2) menjelaskan "penyusutan adalah alokasi jumlah suatu aktiva yang dapat disusutkan sepanjang masa manfaat yang diestimasi.

Menurut IAI (PSAK 2009 : 16.11) metode-metode penyusutan dapat dilakukan dengan berbagai metode yang dapat dikelompokkan menurut kriteria berikut:

a. Metode garis lurus (Stright line method).

Metode ini adalah metode depresiasi yang paling sederhana dan banyak digunakan. Dalam cara ini, beban depresiasi tiap periodenya jumlahnya sama. Besarnya depresiasi yang konstan setiap periode seolah-olah menunjukkan bahwa kemampuan aset tetap relatif sama dalam suatu periode. Padahal kemampuan aset tetap semakin lama menurun dan karenanya kurang logis diterapkan.

Depresiasi $=(\mathrm{HP}-\mathrm{NS}) / \mathrm{n}$

Keterangan:

$$
\begin{array}{ll}
\mathrm{HP} & =\text { Harga Perolehan (cost) } \\
\mathrm{NS} & =\text { Nilai Sisa } \\
\mathrm{N} & =\text { Taksiran Umur Kegunaan }
\end{array}
$$

b. Metode saldo menurun (diminishing balance method).

Metode jumlah menurun ini akan menghasilkan beban penyusutan yang menurun setiap periode. Metode ini beranggapan bahwa aset baru sangat besar peranannya dalam usaha mendapatkan 
penghasilan, peranan aset tersebut semakin lama semakin mengecil seiring dengan semakin tuanya aset tersebut. Tarif pajak dalam metode ini ditentukan terlebih dahulu dan besarnya sama untuk setiap tahun. Penyusutan dihitung dengan mengalikan tarif dengan nilai buku yang semakin kecil.

c. Metode jumlah unit (Sum of the unit method).

Dalam metode ini umur kegunaan/masa manfaat aset tetap ditaksir dalam satuan jumlah unit hasil produksi. Beban penyusutan dihitung dengan dasar satuan hasil produksi, sehingga penyusutan tiap periode akan berfluktuasi sesuai dengan fluktuasi dalam hasil produksi. Dasar teori yang dipakai adalah bahwa suatu aset itu dimiliki untuk menghasilkan produk, sehingga depresiasi juga didasarkan pada jumlah produk yang dapat dihasilkan. Umumnya jumlah hasil produksi yang akan diproses bersifat estimasi sehingga tidak menutup kemungkinan dibelakang hari akan terjadi bahwa estimasi yang dibuat akan lebih rendah, lebih tinggi atau sama dengan kenyataan sesungguhnya.

Definisi diatas menjelaskan bahwa penyusutan adalah pengalokasian harga perolehan aset tetap menjadi beban kedalam periode akuntansi.Dan untuk mengukur beban penyusutan harus menggunakan metode penyusutan yang sesuai serta diterapkan secara konsisten.

\section{Penyajian dan Pengungkapan Aset Tetap}

Dalam laporan keuangan, penyajian aset tetap akan terlihat dalam neraca. Neraca merupakan suatu daftar yang menggambarkan komposisi harta, kewajiban dan modal pada suatu periode tertentu.Aset tetap yang disajikan berdasarkan nilai perolehan aset tersebut dikurangi dengan akumulasi penyusutannya. Setiap jenis aset tetap seperti tanah, bangunan, inventaris kantor dan lain sebagainya harus dinyatakan dalam neraca secara terpisah atau terinci dalam catatan atas laporan keuangan.

Menurut PSAK No.1 paragraf 29 (2009 : 1.2), laporan keuangan yang lengkap terdiri dari komponenkomponen berikut ini:

1. Neraca,

2. Laporan laba rugi,

3. Laporan perubahan ekuitas,

4. Laporan arus kas, dan

5. Catatan atas laporan keuangan.

Menurut PSAK Nomor 16 (2011:16.22), Laporan keuangan mengungkapkan, untuk setiap kelompok aset tetap:

1. Dasar pengukuran yang digunakan dalam menentukan jumlah tercatat bruto,

2. Metode penyusutan yang digunakan,

3. Umur manfaat atau tarif penyusutan yang digunakan,

4. Jumlah tercatat bruto dan akumulasi penyusutan (dijumlahkan dengan akumulasi rugi penurunan nilai) pada awal dan akhir periode, dan

5. Rekonsiliasi jumlah tercatat pada awal dan akhir periode.

Dari uraian diatas dapat diketahui bahwa aset tetap disajikan dalam laporan keuangan sebesar nilai buku saja dan dikurangi dengan akumulasi penyusutan.Dan pengungkapan aset tetap untuk lebih jelas disajikan dalam catatan atas laporan keuangan dan lampiran daftar aset tetap.

\section{Penelitian Terdahulu}

\begin{tabular}{|c|c|c|c|c|c|c|c|}
\hline No & $\begin{array}{c}\text { Nama } \\
\text { Peneliti/ } \\
\text { Tahun }\end{array}$ & Judul & Tujuan & $\begin{array}{l}\text { Metode } \\
\text { Penelitian }\end{array}$ & Hasil Penelitian & Persamaan & Perbedaan \\
\hline 1. & $\begin{array}{l}\text { Shanti } \\
\text { Melisa } \\
\text { (2011) }\end{array}$ & $\begin{array}{l}\text { Perlakuan Akunasi } \\
\text { Aktiva Tetap Dan } \\
\text { Penerapan } \\
\text { Metode Depresiasi } \\
\text { Pada PT Bakrie } \\
\text { Sumatera } \\
\text { Plantations, Tbk. }\end{array}$ & $\begin{array}{l}\text { untuk } \\
\text { mengetahui } \\
\text { apakah } \\
\text { perlakuan } \\
\text { akuntansi } \\
\text { aktiva tetap } \\
\text { dan metode } \\
\text { depresiasi } \\
\text { aktiva tetap } \\
\text { pada PT. } \\
\text { Bakrie } \\
\text { Sumatera } \\
\text { Plantations, } \\
\text { Tbk. telah } \\
\text { sesuai dengan } \\
\text { Standar } \\
\text { Akuntansi } \\
\text { Keuangan. }\end{array}$ & $\begin{array}{l}\text { deskriptif dan } \\
\text { deduktif }\end{array}$ & $\begin{array}{lr}\text { Kebijakan } & \\
\text { Akuntansi } & \text { aktiva } \\
\text { tetap telah } & \text { sesuai } \\
\text { dengan } & \text { Standar } \\
\text { Akuntansi } & \\
\text { Keuangan } & \end{array}$ & $\begin{array}{l}\text { Sama-sama } \\
\text { membahas tentang } \\
\text { aktiva atau aset } \\
\text { tetap }\end{array}$ & $\begin{array}{l}\text { Dalam penelitian } \\
\text { ini tidak } \\
\text { dijelaskan } \\
\text { mengenai metode } \\
\text { depresiasi }\end{array}$ \\
\hline
\end{tabular}




\section{JenisPenelitian}

\section{METODE PENELITIAN}

Jenis penelitian yang digunakan adalah jenis penelitian yang bersifat deskriptif.Menurut Mudrajad Kuncoro (2009: 12) penelitian deskriptif meliputi pengumpulan data untuk diuji hipotesis atau menjawab pertanyaan mengenai status terakhir dari subjek penelitian.Tipe yang paling umum dari penelitian deskriptif ini meliputi penilaian sikap atau pendapat terhadap individu, organisasi, keadaan, ataupun prosedur.Data deskriptif pada umumnya dikumpulkan melalui daftar pertanyaan dalam survey, wawancara ataupun observasi.Data yang telah dikumpulkan, kemudian disusun, diinterprestasikan, dan dianalisa sehingga memberikan keterangan yang lengkap atau gambaran yang sebenarnya tentang perlakuan akuntansi asset tetap pada PT. Massindo Sinar Pratama Manado.

\section{Tempat dan Waktu Penelitian}

Penelitian ini dilakukan pada PT Massindo Sinar Pratama Manado, yang beralamat di Jl. Cereme kelurahan Tuminting Manado.Waktu penelitian secara keseluruhan dilakukan selama 3 bulan, sejak bulan oktober 2013 sampai desember 2013.

\section{ProsedurPenelitian}

Prsedur/langkah-langkah penelitian yang dilakukan oleh penulisa dalah sebagai berikut:

1. Pengamatan dalam bentuk pencanderaan tentang objek yang akan di teliti oleh penulis dengan latar belakang jurusan Akuntansi.

2. Dipilihnya PT Massindo Sinar Pratama Manado sebagai lokasi dan objek penelitian.

3. Peneliti selanjutnya mengkonsultasikan judul penelitian kepada Ketua Laboratorium, dosen Pembimbing.

4. Setelah disetujinya judul penelitian kemudian penulis mengajukan permohonan ijin penelitian kepada Fakultas Ekonomi dan Bisnis yang ditujukan kepada PT MassindoSinarPratama Manado.

5. Peneliti melakukan pengumpulan data berupa wawancara, kemudian mempelajari dokumend, serta literatur/buku, jurnal, sesuai kebutuhan.

6. Peneliti mengidentifikasi, mengklasifikasikan, menganalisis, kemudian membuat draft/konsep penelitian.

7. Draft/konsep penulisan dikonsultasikan dengan dosen pembimbing untukd iperbaiki.

8. Menulis skripsi sesuai pedoman/panduan yang diterbitkan oleh fakultas ekonomiUniversitas Sam Ratulangi Manado.

\section{PopulasidanSampel}

Menurut Sugiono (2012:216) dalam penelitian kualitati ftidak menggunakan populasi, karena penelitian kualitatif berangkat dari kasus tertentu yang ada pada situasi sosial tertentu dan hasil kajiannya tidak akan diberlakukan ke populasi, tetapi ditransferkan ke tempat lain pada situasi sosial yang memiliki kesamaan dengan situasi pada kasus yang di pelajari. Sampel dalam penelitian kualitatif bukan dinamakan responden, tetapi sebagai nara sumber atau partisipan, informan, teman, dan guru dalam penelitian. Sampel dalam penelitian kualitatif, juga bukan disebut sampel statistik, tetapi sampel teoritis, karena tujuan penelitian kualitatif adalah untuk menghasilkan teori.

\section{Metode Pengumpulan Data}

Menurut Kuncoro (2009:124) "Data adalah sekumpulan informasi yang diperlukan untuk pengambilan keputusan". Data penelitian dapat diperoleh dari berbagai sumber yang dikumpulkan dengan menggunakan berbagai teknik selama kegiatan penelitian berlangsung.

\section{Jenis Data}

Jenis data yang digunakan pada mumnya adalah sebagai berikut:

a. Data Kualitatif adalah data yang berbentuk kata-kata, bukan dalam bentu kangka. Data kualitatif diperoleh melalui berbagai teknik pengumpulan data misalny awawancara, analisis dokumen, diskusi terfokus, atau observasi. Dalam penelitian ini menggunakan data kualitatif.

b. Data kuantitatif adalah data yang berbentuk angka atau bilangan. Dalam penelitian ini data kuantitatif tidak digunakan.

\section{Sumber Data}

Berdasarkan sumbernya, data penelitian dapat dikelompokkan dalam dua jenis yaitu, data primer dan data sekunder. 
1. Data primer adalah data yang diperoleh atau dihimpun oleh peneliti secara langsung dari sumber datanya yang diperoleh dari teknik wawancara, kemudian akan diolah oleh penulis, seperti wawancara dengan staf bagian yang berhubungan dengan penelitian tersebut.

2. Data sekunder adalah data yang diperoleh dari perusahaan dalam bentuk yang sudah jadi, seperti data mengenai sejarah singkat perusahaan, struktur organisasi, tentang pembagian tugas, dan datadata lainnya yang berhubungan dengan aset tetap.

\section{TeknikPengumpulan Data}

\section{Interview / wawancara}

Penulis melakukan serangkaian tanya jawab secara langsung dengan pihak perusahaan yang berwenang, yaitu bagian akuntansi untuk mendapatkan informasi tentang aset tetap.

2. StudiKepustakaan (Library Research)

Pengumpulan data melaluikepustakaanadalahmetodepenelitiandenganmengumpulkan

\section{MetodeAnalisis} data yang berkaitandenganpenelitian yang berasaldaribuku-bukudanliteratur-literatur.

Analisis data yang dilakukan adalah dengan menggunakan metode :

1. Deskriptif

Metode dimana data dikumpulkan, disusun, diinterpretasikan dan dianalisis sehingga memberikan keterangan yang lengkap bagi masalah yang dihadapi.

2. Komparatif

Metode analisis yang dilakukan dengan membandingkan teori-teori dengan praktik yang terjadi di dalam perusahaan, kemudian mengambil kesimpulan dari hasil perbandingan tersebut.

Metode analisis data yang digunakan penelitian ini adalahMetode analisis deskriptif-komparatif, dimana penelitian dilakukan dengan mengumpulkan data asett etap yang ada di perusahaan dan menganalisa data yang dikumpulkan serta memberi keterangan-keterangan yang dihadapi. Alasan digunakan metode ini, peneliti bisa menganalisa masalah, membandingkan data yang dikumpulkan dilapangan dengan teori yang dipelajari dan merumuskan penyelesaian yang ada pada masa yang akan dating. Metode ini bias membantu dalam mengidentifikasi aktor-faktor yang berguna dalam pelaksanaan penelitian dan dapat digunakan untuk menggambarkan keadaan yang mungkin dapat terjadi dalam situasi tertentu.

\section{DefinisiOperasional} Manado"

Judul penelitian yaitu :“Analisis Perlakuan Akuntansi Aset Tetap pada PT. Massindo Sinar Pratama

1. Pengakuan Aset Tetap adalah dimana aset yang memiliki nilai diperoleh perusahaan dan diakui sebagai harta perusahaan, serta biayanya dapat dihitung secara andal

2. Penilaian asset tetap adalah dimulai pada saat diakui sebesar dengan biaya perolehan asset tersebut.

3. Pengeluaran asset tetap setelah diperoleh dan diakui adalah bentuk pemeliharaan serta upaya untuk menambah masa manfaat dari asset tetap.

4. Penyusutan asset tetap adalah pengalokasian nilai aset yang dihitung pertahun dan dijadikan pengurang nilai asset tetap dari saat perolehan.

5. Pelepasan asset tetap merupakan perlakuan entitas untuk menghentikan penggunaan asset tetap yang telah habis umur manfaat dan idak bisa menambah manfaat ekonomis lagi bagi perusahaan, serta menghapus pencatatan nilai asset tetap dari laporan keuangan.

6. Penyajian dan Pengungkapan adalah perlakuan untuk menyajikan asset tetap dalam laporan keuangan serta mengungkapkan dasar-dasar pengukuran yang digunakan, metode penyusutan yang digunakan serta beberapa hal lainnya yang diungkapkan dalam catatan atas laporan keuangan.

\section{Gambaran Umum Obyek Penelitian}

\section{HASIL PENELITIAN DAN PEMBAHASAN}

PT. Massindo Sinar Pratama adalah salah satu perusahaan swasta yang ada di Manado, Sulawesi Utara yang bergerak di bidang manufaktur.Ada empat jenis produk yang dihasilkan yaitu Kasur Busa, Plastik Rabbit, Sofa dan Spring Bed.Perusahaan ini didirikan pada bulan Januari tahun 1984 oleh seorang pengusaha bernama William Massie dan pada awalnya perusahaan ini bernama CV. Abadi Jaya Bersama. Produk awalnya pada waktu itu adalah Busa dan Sofa kemudian berkembang dengan didirikannya pabrik Plastik Intection pada tahun 1989 yang memproduksi barang-barang plastik dengan Rabbit Star yang digunakan untuk keperluan rumah tangga dan diresmikan oleh Presiden Republik Indonesia Bapak Soeharto yang diwakili oleh Menteri Perindustrian Republik Indonesia Bapak Hartanto pada tahun 1993.Dengan adanya upaya-upaya yang dilakukan 
oleh perusahaan dalam rangka mengembangkan serta meningkatkan produktifvtas

ini maka pada tahun 1995 perusahaan ini dinilai layak oleh pemerintah untuk menerima penghargaan di bidang produktivitas berupa trophy "Sidakarya". Di dalam menghadapi persaingan di pasar internasional maka pada tanggal 10 Desember 1998 di kantor Notaris Thressje Sembung, SH perusahaan berganti nama menjadi PT. Massindo Sinar Pratama dan perusahaan ini dipegang oleh Massindo Group yang memiliki kantor pusat di Jakarta, hal ini disebabkan ibukota Negara Republik Indonesia.

\section{Hasil Penelitian dan Pembahasan}

Sebagai perusahaan manufaktur, PT Massindo sinar Pratama memerlukan Aset tetap dalam menjalankan kegiatan operasionalnya.Aset tetap merupakan aset terbesar dalam neraca perusahaan.Untuk itu pengelolaan aset tetap dan pembebanan pada setiap produk merupakan hal yang sangat penting bagi perusahaan.Sehingga dalam penentuan rugi atau laba perusahaan dapat dilakukan dengan memadai.Pada pembahasan ini difokuskan pada satu aset tetap yaitu mesin produksi.Ini dilakukan karena dalam kegiatan utama PT. Massindo Sinar Pratama adalah memproduksi spring bed dan menggunakan beberapa mesin produksi. Pembahasan dilakukan dalam beberapa tahap sebagai berikut ; pengakuan aset tetap, pengukuran aset tetap, pengeluaran-pengeluaran untuk aset tetap setelah perolehan, penyusutan aset tetap, pelepasan aset tetap, penyajian dan pengungkapan aseta tetap dalam laporan keuangan.

\section{Pengakuan Aset Tetap}

Dalam mendapatkan mesin, PT. Massindo Sinar Pratama melakukan pembelian dari perusahaan di luar negeri. Proses pembelian dilakukan dengan beberapa persyaratan antar kedua perusahaan. Persyaratan yang disepakati dituangkan dalam perjanjian jual beli barang, diantaranya berisikan bahwa barang dijamin samapai pada perusahaan pembeli (PT.Massindo Sinar Pratama). Hal lain yang berkaitan dengan berfugsinya mesin tersebut menjadi tanggungan pembeli. Hal ini karena perusahaan penjual telah memberikan bantuan teknis kepada perusahaan pembeli.

Memperhatikan syarat jual beli maka dapat dikatakan bahwa pengakuan hak milik atas mesin tersebut yaitu pada saat diterimanya mesin.Pada saat diterimanya barang tersebut, bagian penerima barang mencatat pada kartu aktiva tetap dan meberikan dokumen-dokumen lain kepada fungsi yang terkait diantaranya fungsi akuntansi.Fungsi akuntansi melakukan pencatatan atas penerimaanbarang tersebut dengan mendebet rekening mesin dan mengkredit rekening hutang dagang.

Bila dikaitkan dengan teori yang telah diuraikan pada bab 2 di atas maka dapat dikatakan bahwa proses pengakuan atas aktiva mesin yang dilakukan oleh perusahaan dapat dikatakan telah memadai karena telah memperhatikan syarat perjanjian jual beli barang. Dimana barang berpindah hak setelah barang tersebut diterima oleh pembeli.

\section{Pengukuran Aktiva Tetap}

Sebelum menggunakan mesin tersebut diatas, perusahaan menyediakan tempat untuk menempatkan mesin tersebut dalam bentuk konstruksi tertentu. Dalam konstruksi tersebut peusahaan mengeluarkan sejumlah dana sampai selesai konstruksi tersebut. Pengeluaran dana diberikan dalam 2 tahap kepada kontraktor yaitu tahap pertama $30 \%$ dan tahap kedua $70 \%$ setelah selesai konstruksi. Penyerahan dana 30\% perusahaan melakukan pencatatan dengan mendebet rekening Piutang Lain dan mengkredit rekening Kas. Setelah selesai pekerjaan tersebut, perusahaan mendebet rekening Mesin dan mengkredit rekening Kas dan Piutang Lain.

Bila dikaitkan dengan teori yang telah diuraikan pada bab 2 di atas maka dapat dikatakan bahwa proses pengukuran atas aktiva mesin tersebut telah memadai karena unsur-unsur yang membentuk perolehan mesin telah dimasukkan sebagai satu kesatuan harga.

\section{Pengeluaran Setelah Perolehan Aktiva Tetap}

Perusahaan telah menetapkan kebijakan terhadap pengeluaran-pengeluaran yang berkaitan dengan aktiva tetap. Dimana pengeluaran di bawah Rp. 10.000.000,- (sepuluh juta rupiah) diperlakukan sebagai biaya pemeliharaan aktiva tetap. Selama kurun waktu pembelian sampai saat dimana dilakukan penelitian ini, perusahaan belum melakukan pengeluaran terhadap aktiva tetap dalam jumlah yang melebihi nilai diatas sepuluh juta rupiah.Setiap pengeluaran kas terhadap aktiva mesin dicatat dengan mendebet rekening Biaya Pemeliharaan dan mengkredit rekening Kas.

Bila dihubungkan dengan teori yang ada pada bab 2 di atas, maka pencatatan yang dilakukan telah memadai karena telah memperhatikan kebijkan perusahaan dimana pengeluaran tersebut tidak menambah masa manfaat atau mutu bahkan peningkatan kapasitas. 


\section{Penyusutan Aktiva Tetap}

Aktiva tetap yang digunakan perusahaan diklasifikasikan ke dalam beberapa golongan lain yaitu; Tanah, Bangunan, Mesin, Kendaraan, dan Peralatan.Pengelompokkan untuk penyusutan aktiva tetap disesuaikan dengan ketentuan perpajakan yang ada.Ini dilakukan untuk mempermudah dalam penyusunan laporan keuangan.Karena metode yang digunakan tidak menyimpang dengan Standar Akuntansi Keuangan yang berlaku.Pencatatan atas penyusutan mesin adalah dengan mendebet rekening Penyusutan Mesin dan mengkredit rekening Akumulasi Penyusutan Mesin.

Bila dihubungkan dengan teori yang ada pada bab 2 di atas maka dapat dikatakan bahwa baik pengelompokkan dan pembebanan penyusutan untuk tujuan penyajian laporan keuangan perusahaan telah memadai.

\section{Penyajian dan Pengungkapan Aktiva Tetap}

Dalam Penyajian Laporan Keuangan perusahaan khususnya yang berkaitan dengan aktiva tetap, perusahaan menyajikanya sebagai berikut ;

\begin{tabular}{|c|c|c|}
\hline Tanah & & Rp. XXX \\
\hline Bangunan & Rp. XXX & \\
\hline $\begin{array}{c}\text { Akumulasi Penyusutan Gedung } \\
\text { Nilai Buku Bangunan }\end{array}$ & (Rp. XXX) & $\operatorname{Rp} . X$ \\
\hline Mesin & Rp. XXX & \\
\hline $\begin{array}{c}\text { Akumulasi Penyusutan Mesin } \\
\text { Nilai buku Mesin }\end{array}$ & $(\mathrm{Rn} X X X)$ & Ro. XX \\
\hline Peralatan & Rp. XXX & \\
\hline $\begin{array}{c}\text { Akumulasi Penyusutan Peralatan } \\
\text { Nilai Buku Peralatan }\end{array}$ & (Rp. XXX) & Rp. X \\
\hline TOTAL AKTIVA TETAP & & Rp. X \\
\hline
\end{tabular}

Tidak ada pengungkapan atas aktiva tetap yang disajikan perusahaan karena perusahaan tidak melakukan perubahan metode penyusutan atas aktiva tetap yang digunakan.

\section{Kesimpulan}

\section{PENUTUP}

Berdasarkan teori dan pembahasan yang dilakukan maka dapat diberikan beberapa kesimpulan sebagai berikut ;

1. Pengakuan aktiva tetap khususnya mesin telah sesuai dengan Standar Akuntansi Keuangan yang ada

2. Perusahaan telah memasukkan unsur-unsur yang membentuk nilai perolehan dari Mesin yang di beli, sehingga pengukuran atas nilai perolehan Mesin telah sesuai dengan Standar Akuntansi Keuangan yang ada.

3. Perlakuan atas pengeluaran-pengeluaran untuk aktiva tetap khususnya Mesin sebagai unsur Biaya Pemeliharaan dalam mana pengeluaran tersebut tidak menambah masa manfaat dan meningkatkan standar kinerja telah sesuai dengan Standar Akuntansi Keuangan yang ada

4. Metode penyusutan dan pembebanan pada laporan keuangan perusahaan telah dilakukan secara memadai dan sesuai dengan Standar Akuntansi Keuangan yang ada

5. Penyajian aktiva tetap pada laporan keuangan telah memadai dan sesuai dengan Kaidah Standar Akuntansi Keuangan yang ada

\section{Saran}

Proses pencatatan yang dibuat perusahaan sehubungan dengan pembangunan atau pekerjaan tempat untuk mesin ada baiknya dengan mencatat dengan mendebet rekening Pekerjaan dalam Penyelesaian Mesin bukan Piutang Lain. Karena makna pengertian Piutang Lain adalah peusahaan mempunyai hak untuk menagih kepada pihak ketiga karena menyerahkan suatu jasa atau barang kepada pihak tersebut di masa lalu.

Adapun proses pencatatan yang dapat dikoreksi adalah dengan mendebet rekening Pekerjaandalam Penyelesaian Mesin dan mengkredit rekening Piutang Lain. 


\section{DAFTAR PUSTAKA}

Harahap, S.S. 2007. A Statement of Basic Accounting Theory (ASOBAT), Penerbit PT Raja Grafindo Persada, Jakarta

Hery, 2013.TeoriAkuntansiSuatuPengantar. PenerbirFakultasEkonomiUniversitas Indonesia, Jakarta.

Hery,2013. AkuntansiDasar 1 dan 2.Penerbit PT Grassindo, Jakarta

Horngren. Charles. T dan Walter T. Harrison Jr. 2009.Akuntansi.Jilid 1.PenerbitErlangga, Jakarta.

IkatanAkuntan Indonesia (IAI).2009.StandarAkuntansiKeuangan, SalembaEmpat, Jakarta.

Kirana, Putra. 2013. PerlakuanAkuntansiAsetTetapberdasarkan PSAK No. 16 pada PT. GraphikaBetonUniversitasMaritim Raja Ali Haji, Tanjungpinang

Mardiasmo. 2011. Perpajakan, EdisiRevisi 2011. PenerbitAndi Offset, Yogyakarta

Melisa, Shanti. 2011. PerlakuanAkuntansiAktivaTetap Dan PenerapanMetodeDepresiasiPada PT Bakrie Sumatera Plantations, Tbk.Universitas Sumatera Utara, Medan.

Mudrajad Kuncoro, Ph.D, 2009. Metode Riset untuk Bisnis dan Ekonomi, Edisi ketiga, Penerbit Erlangga, Jakarta.

Sumarsan, Thomas. 2011. AkuntansiDasar\&AplikasidalamBisnis, cetakanpertama.Penerbit PT Indeks, Jakarta Barat.

Sugiyono, 2012.MetodePenelitianKuantitatifKualitatifdan R\&B. cetakan ke-15.Alfabeta, Bandung.

Suharli, Michell. 2006. AkuntansiUntukBisnisJasadanDagang, EdisiPertama.PenerbitGrahallmu, Yogyakarta.

Suhayati, Ely. dan Sri, D. Anggadini. 2009. AkuntansiKeuangan.PenerbitGrahaIlmu, Yogyakarta

Sumadji.Pratama.dan Rosita. 2006. KamusEkonomi. Penerbit WIPRESS, Jakarta.

Putra, T. Mandala. 2013. "Analisis Penerapan Akuntansi Aset Tetap pada cv. kombos manado". Jurnal EMBA. Vol.1 No.3. Hal. 190-198. 